\title{
Albanian Technical Terminologies as a Special Vocabulary and Its Challenges in the XXI Century
}

\author{
Gani Pllana* \\ University of Prishtina "Hasan Prishtina”, \\ Prishtina, Republic of Kosovo \\ Sadete Pllana \\ University of Prishtina "Hasan Prishtina", \\ Prishtina, Republic of Kosovo
}

\begin{abstract}
In the conditions of the rapid development of technics and technology in recent years, the cooperation of the scientific-technical language with the standard Albanian language is continuing with a higher intensity than before. We notice a vigor of enrichment in the vocabulary of technical terminology, due to the creation and formation of new fields and subfields of technics, technology, also computing, mechatronics, telemetry, a multitude of concepts many of which, on one hand, are marked with names of the languages they come from, mainly from English, but on the other hand, they meet their needs with the lexical mother tongue composition (by common words being raised to terms) and with the activation of other layers, such as word-combination (word-group) terms. In this paper, in a more pronounced way, we are exploring with priority the formation process of terms from common words in technical terminologies. The influence of the scientific-technical language on the general one will be further strengthened in future, because science and its language are beginning to play an increasingly more important role on the development of culture in general.
\end{abstract}

Keywords: terms, Albanian technical terminology, problems, tasks, XXI century

\section{Introduction}

Given the fact that within a paper it is relatively difficult to include and evaluate all the achievements and problems of Albanian terminology from its beginnings until today, so it remains to present here in general only some of the basic achievements and then also some problems that stand today in front of the Albanian terminology, waiting to be discussed and solved according to national and international norms and standards.

Unfortunately, Albanian terminology as a separate field of study has started to be cultured and crystallized relatively late, from the period of Albanian Renaissance, especially by the continuous work of the great renaissance representatives, such as: Naim Frashëri, Sami Frashëri, Jani Vreto, etc. 
The mechanical industry, in the Albanian area, until 1945 was represented by some workshops with small production or in general with repair character, which were in the hands of foreign and domestic capital, where the technical literature published in this period was very small. With the wide and in-depth development of science and technology at the international and national levels, the fields of knowledge increased and differentiated so much that their filling with terms could be done primarily through foreign terms, which flooded into to a large extent, especially in high school and high school textbooks, as well as in scientific and technical documents, in manuals of all kinds, or simply used in teaching.

From the beginning of the $20^{\text {th }}$ century, the process of entering into Albanian mainly words from Italian, French, Russian, German and English language, which have functioned as terms, has almost completely included the school lexicon and in particular that part which is related to terminologies of various fields of knowledge, starting from the formation of these terminologies (in their basic fields, such as mathematics, physics, geometry, etc.), when they appear crystallized and finally formed as sustainable and homogeneous systems.

However, the reliance on a fair language policy in the field of terminology, implementing the basic orientation of this policy, that the intervention of society in terminology is necessary and possible, and which led to the establishment of committees and relevant bodies that worked in this issue. This made it possible to put a part of foreign terms through Albanian terms as their substitutes, which were reflected in many dictionaries of different types, such as explanatory -linguistic, terminological (Fjalor, 1970:5-8), teaching and translation.

\section{Characteristics of Term}

Based on linguistic studies of terminology problems, there are different definitions for the term. The term is defined, as:

words or word-combinations, linguistic sign which refer to the responsible notion in the system of notions of a field of science or technology,

words or word-combinations of a special sphere of use which is the name of a scientific notion and has a definition,

words or word-combinations that serve to the communication of people united by a common profession or specialist.

Some authors define the term as:

unit of the terminological system that names a notion and its place in the system, among other notions,

part of a certain system which names a notion in the system of notions of a certain science or field of production.

As for the characteristics of the term, from the definitions given by the dictionaries, it follows that:

the term is a special word or expression for a certain branch (Fjalor, 1954:561);

well-defined and punctual denomination; words or phrases that express a certain notion and are used by a certain group of people (Fjalor, 1980:1987). 


\subsection{The difference between the term and the word}

Each term has its own scope within the boundaries of a terminology and from a semantic point of view, is unambiguous as opposed to the word being ambiguous. The term differs from the word in general lexicon by the specialization of meaning and the accuracy of semantic boundaries. Thus, the difference lays not so much in the plane of expression, since the formation of terms is done according to the same rules, but in the plane of content.

Another difference between the term and the word is also noticed in that the term does not depend on the context, it is not related to the context, but to the terminological field, which replaces the context; so its meaning is clear only by knowing what terminological field it belongs to, without having to be in context.

Given the peculiarities of the term and its differences from the word of the general language, from the nomenclature designation and from the professionalisms it emerges that the term is a lexical-grammatical unit with special use that functions in a certain terminological system, within the terminology of a certain field.

The terminology of a language as a special lexicon is studied in the form of terminologies of specific fields of knowledge, where each field constitutes a system of terms that corresponds to a system of concepts of that field of knowledge. Thus, the identity of any terminology thus constitutes the field of knowledge. Work with terminology begins with the concept, which constitutes the content of the term. Within the system is placed the equation a concept/a term. This is also the basis of standardization, which is solved through the avoidance of synonymy and homonymy. The term by the form is national, by the content is international; in meantime the nationality of the term (by the form) from the internationality (by the content, the concept) takes on special value for the national, nationwide and international standardization of any terminology (Wüster, 1968:2).

\section{Theoretical Studies of Terminology Undertaken by Local and Foreign Linguists}

As a basis for continuing the development and amendment of dictionaries with new terms, we should also use the theoretical studies undertaken by local and foreign linguists, where in the first place are used works related to problems of technical fields both for genuine theoretical issues, as well as for aspects related to implementation issues of terminological principles in the practice of processing terms and their reflection in relevant dictionaries; of Albanian terminologists (from Albania and Kosovo), as: Lirak Dodbiba, Ferdinand Leka, Hëna Pasho, Agron Duro, Vladimir Dervishi, Hasan Çipuri, Esat Stavileci, Nebi Caka, Vilma Proko-Jazexhiu, Latif Susuri, Flutura Çitaku, Gani Pllana, Sadete Pllana, Hajrullah Gorani, Pajazit Nushi, as well as in the works of foreign terminologists, like: Eugen Wüster, Juan C. Sager, H. Piht, Helmut Felber, V. Lotte etc. In particular, the main place in terminology is occupied by the works of Eugen Wüster, Austria and V. Lotte, since these two authors have made the object of their study most of the two important fields of knowledge, identified at that time (in the 30s of the $20^{\text {th }}$ century), such as today, mechanics and electricity, to which are challenges for Albanian technical terminology in the $21^{\text {st }}$ century. It should be noted that by Eugen Wüster, who has also been described as the father of terminology at the international level, I have relied on the general principles of terminology and the methods of its elaboration, addressed in his terminological work "The machine tool". In addition to the works of terminologists as a point of reference have served the genuine theoretical works and special scientific articles of Albanian linguists, who have also dealt with problems of terminology, as can be mentioned: 
Alekasndër Xhuvani, Androklli Kostallari, Jani Thomai, Miqo Samara, Emil Lafe, Xhevat Lloshi, Sadete Pllana, Flutura Çitaku, etc. (Pllana, 2014:22-23)

\section{Organization of Albanian Technical Terminologies}

The most basic activity in the field of terminological lexicon is related to the collection of terminological material, its processing and reflection in the relevant dictionaries. This belongs to the third phase, after the 50 s of the $20^{\text {th }}$ century, in which this whole process took place in two directions: firstly, work on an institutionalized basis, with a clear strategy, which became predominant with the establishment of the Institute of Standard Language in 1948 and especially the Terminology Sector in 1955, aiming at systematizing, unifying and Albanianizing the terminologies of different fields of knowledge. As a result of that, a series of terminological dictionaries came to light, such as the dictionary of botany, mathematics, chemistry, etc. (since 1963); each field of terminology was built on the basis of the fundamentals of the Albanian language and its word-forming models; secondly, it was done on individual basis, or in cooperation with specialized centers in this field. This activity initially was rarer, but later was intensified, especially with bilingual dictionaries (foreign language Albanian).

Nowadays the department builds its work in three main directions: in lexicology, terminology and applied linguistics. The department consistently has had a qualified and specialized scientific body and for about 50 years has designed and released dozens of works, which have been evaluated and have taken place in the fund of our national culture (Thomai, 2017:12121).

The work in terminology is organized in studies on term and terminology as well as in the compilation of terminological works (compilation of terminological dictionaries of Albanian).

In Prishtina, Albanian Language Institute organized the scientific session "The state of Albanian terminology in Yugoslavia", on 28 and 29 January 1988, where in addition to the works of linguists related to terminology were presented works by researchers in other fields (various specialists).

In Tirana, by the Albanian Academy of Sciences and Arts, and the Kosovo Academy of Sciences and Arts was organized the scientific conference "State and development of Albanian terminology problems and tasks", June 2009 (Pasha \& Duro, 2009:21), with the participation of prominent terminologists from Albanian territories.

\section{Albanian Terms Based on Common Words that Mark Parts of the Human Body}

A separate problem is the standardization of terminology and in particular the introduction in the process of standardization of Albanian terms based on common words, which serve as key elements in solving the problems of systematization and Albanianization of terminology (Kostallari, 2017:288).

Words that mark parts of the human body are widely used in the process of transition from word to word meaning with specialized use in various fields of science and technology. The concepts that mark these words are introduced into the system of concepts of the given field, further expanding and enriching the connections between them. The ability of these common words to create terms is related to the approximate aspect that the word has with its form and function with the concept that is required to be marked. Thus the meaning of the word arm $_{1}$ (of person) from the form of the function it performs resembles the arm (of a crane), as a new 
concept, therefore the name arm 2 (of a person) is given to the concept that is required to be marked (Pllana, 2017: 112).

These word-terms, with the concepts they mark, are inserted into the conceptual system of the given field by expressing other concepts within the field.

In the following examples we will present the cases of common words, the parts of the human body, which through the process of terminology are raised into words with specialized meaning, in terms, reflected in Dictionary 1980 and concretized as markers of meanings in the terminology of technical fields, giving in a coded way the source where the word was used for the first time (Fjalor, 2002):

ballë/fore: fore 1 (of gallery) (min), fore 2 (of piston) (mech.), fore 3 (of cartridges) (mil.),

brinjë/rib: rib1 (of boat) (sea); rib2 (of radiator) (mech.);

buzë/edge: edge 1 (of dish) (mech.), edge 2 (of road) (cons.), edge 3 (of vice) (mech.),

dhëmbë/tooth: tooth ${ }_{1}$ (of wheel) (mech.); tooth 2 (of rake) (agriculture); tooth 3 (of drag) (agriculture);

dorë/hand: hand 1 (of fastener) (mech.); hand2 (of manipulator) (rob.);

flegër/fold: fold 1 (of window) (cons.); fold 2 (of valve) (mech.);

gisht/finger: finger 1 (of valve combine harvester) (agriculture.); finger 2 (of piston) (mech.);

gju/knee: knee (axel) (mech.);

gojë/mouth: mouth 1 (of pipe) (mech.); mouth 2 (of volcano) (min.); gojë/mouth 3 (of plank) (cons.);

grusht/fist: fist 1 (hydraulic) (mech.);

grykë/throat: throat 1 (of well) (min.); throat2 (of volcano) (geol.);

hundë/nose: nose 1 (of hammer) (mech.), nose 2 (of ship) (sea),

këmbë/feet: foot 1 (of motorbike) (mech.); foot 2 (of bridge) (cons.); këmbë/foot 3 (of mineral) (min.);

kokë/head: head 1 (of bolt) (mech.), head 2 (of nail) (mech.), head 3 (of milling) (mech.),

krah/arm: karm $_{1}$ (of excavator) (const., mech.); $\operatorname{arm}_{2}$ (of crane) (const., mech.); arm3(of jack) (mech.);

kryq/cross: $\operatorname{cross}_{1}$ (of mechanism) (mech., cosn.); cross2 (of road) (cons.);

kyç/joint: joint, (of closing) (construction); joint2 (of link) (mech., elec.);

nyjë/not: not ${ }_{1}$ (of rope) (mech. cons.); not 2 (of string) (teks/textile.); nyjë/not (of railway) (comm.);

qafë/neck: /neck (of bolt) (mech.); neck2 (of axel) (mech.); neck3 (of pipe) (mech.);

shputë/foot: foot (of pillar) (cons.);

sup/shoulder: shoulder(of lifter) (mech.); 
sy/eye: eye 1 (of loop) (mch.); eye 2 (of piston) (mech.);

$\begin{array}{lll}\text { trup/body: body } 1 \text { (of } & \text { screw) (mech.), body } 2 \text { (of } & \text { ship) (sea.), body } y_{3} \text { (of } \\ \text { engine) (mechanism), body4 (of bolt) (mech.) }\end{array}$

vesh/ear: ear1 (of nut) (mech.), ear2 (of fork) (agric.) etc.

zemër/heart: heart ${ }_{1}$ (of wood) (forestry); heart $($ ofform) (met.); zemër/heart3 (of cable) (el.);

\section{Conclusion}

On this situation in which is today, the Albanian technical terminology I can give recommendations regarding the necessity of compiling dictionaries of special technical subfields, mechanics, electricity, informatics, mechatronics and construction, which will be realized in cooperation with specialists and linguists. Also of particular interest would be the compilation of a basic technical vocabulary, of a basic systemic dictionary with definitions for technical terminologies, built according to computer methods.

The meanings of the terms based on the meanings of ordinary words are reflected in the explanatory dictionaries of Albanian in the semantic structures of their words. The study of these meanings of words, when they appear as terms like foot (word) and foot (term) and which are distinguished as such during use in the respective field of knowledge, gives the opportunity to examine this lexical intermediate layer in relation to the general lexicon, with other groups of terminological lexicon, as well as with cases of functioning in the teaching practice of each field.

The problems of standardization should be considered closely related to the solution of general problems of dual problems in terminology and synonymy and polysemy as harmful phenomena for terminology and in particular for technical terminology.

The solution of the problems of standardization, setting standard and normative terms should be carried out on the basis of strict scientific principles and criteria of terminology as a science and as a practical activity, such as in the first place the requirements of accuracy and clarity of terms, setting of term-concept equivalents and vice versa to create for each field of knowledge a terminological system, to respond adequately to the respective conceptual system. On this basis, the problems of absolute synonymy (doublet), which overload the terminology, of relative synonymy (quasi-synonyms and pseudo-synonyms), which create confusion in scientific-technical communication and reduce its quality, must be solved.

\section{References}

[1] Beer, F. etc. Vector Mechanics for Engineers Statics, p. 220, McGraw-Hill, New York, 2004.

[2] Duro, A. Termi dhe fjala në gjuhën shqipe (në rrafshin e formës dhe të përmbajtjes, QSA IGJL,

[3] p. 175, Tiranë, 2009.

[4] Fjalor i terminologjisë tekniko-shkencore, Terminologjia e matematikës dhe e mekanikës

[5] teorike, shqip-serbokroatisht-rusisht-frëngjisht, Prishtinë, 1969. [In Albanian]

[6] Fjalor i gjuhës shqipe (1954), Tiranë, 1954.

[7] Fjalor i gjuhës së sotme shqipe (1980), Tiranë, 1980.

[8] Fjalor i gjuhës shqipe (2006), ASHSH IGJL: Tiranë., 2006. 
[9] Fjalor i termave themelorë të mekanikës SHQIP-ANGLISHT-FRËNGJISHTITALISHT-

[10] RUSISHT, Tiranë, 2002.

[11] Fjalor i terminologjisë tekniko-shkencore TERMINOLOGJIA E BOTANIKËS 1 shqip-

[12] serbokroatisht-rusisht-frëngjisht, p. 5-8, Prishtinë, 1970.

[13] Kostallari, A. Histori e gjuhësisë së përgjithshme fjalë formimi i shqpes gjuha e sotme shqipe,

[14] Vëllimi III, p. 288, Tiranë, 2018.

[15] Kurti, S. etj.-etc. Fjalor politeknik anglisht-shqip - English-Albanian Polytechnic Dictionary,

[16] Tiranë, 1991.

[17] Pllana, G. Formimi i terminologjive teknike shqipe mbi bazën e leksikut të përgjithshëm

[18] (Procese të krijimit, të pasqyrimit në gjuhë dhe të standardizimit), QSA IGJL, Botimet

[19] Albanologjike, p. 9 \&217, Tiranë, 2017.

[20] Pllana, G.; Pllana, S.; Breznica P. A. (2020), Technical terms formed on the basis of the meanings of

[21] common words in the dictionaries of the Albanian language 1980 and 2006, RUSSIAN LINGUISTIC

[22] BULLETIN 3 (23) 2020, p. 121-124, Yekaterinburg, 2020.

[23] Shvarts, V. V. The concise illustrated Russian-English dictionary of Mechanical Engineering,

[24] p. 53, Moscow, 1980.

[25] Thomai, J. Studime për gjuhën shqipe IV, ASA IGJL, p. 120-122, Tiranë, 2017.

[26] Beer, F. etc. Vector Mechanics for Engineers Statics, p. 220, McGraw-Hill, New York, 2004.

[27] Duro, A. Termi dhe fjala në gjuhën shqipe (në rrafshin e formës dhe të përmbajtjes - Term and

[28] word in Albanian language (in terms of form and content), QSA IGJL, p. 175, Tiranë, 2009. [In

[29] Albanian]

[30] 3. Fjalor i terminologjisë tekniko-shkencore, Terminologjia e matematikës dhe e mekanikës

[31] teorike, shqip-serbokroatisht-rusisht-frëngjisht - Dictionary of technicalscientific terminology,

[32] Mathematics and theoretical mechanics terminology, Albanian-Serbo-CroatianRussian-

[33] French, Prishtinë, 1969. [In Albanian]

[34] 4. Fjalor i gjuhës shqipe - Dictionary of the Albanian language (1954), Tiranë, 1954. [In Albanian]

[35] 5. Fjalor i gjuhës së sotme shqipe-Dictionary of today's Albanian language (1980), Tiranë, 1980.

[36] [In Albanian]

[37] 6. Fjalor i gjuhës shqipe - Dictionary of the Albanian language (2006), ASHSH IGJL: Tiranë, 
[38] 2006. [In Albanian]

[39] 7. Fjalor i termave themelorë të mekanikës SHQIP-ANGLISHT-FRËNGJISHTITALISHT-

[40] RUSISHT - Dictionary of basic terms of mechanics ALBANIAN-ENGLISHFRENCH-

[41] ITALIAN-RUSSIAN Tiranë, 2002. [In Albanian]

[42] 8. Fjalor i terminologjisë tekniko-shkencore TERMINOLOGJIA E BOTANIKËS 1 shqip-

[43] serbokroatisht-rusisht-frëngjisht- Dictionary of technical-scientific terminology BOTANICAL

[44] TERMINOLOGY 1 Albanian-Serbo-Croatian-Russian-French, p. 5-8, Prishtinë, 1970. . [In

[45] Albanian]

[46] 9. Kostallari, A. Histori e gjuhësisë së përgjithshme fjalë formimi i shqpes gjuha e sotme shqipe

[47] History of general linguistics word formation of the Albanian language today, Vëllimi -

[48] Volume III, p. 288, Tiranë, 2018. [In Albanian]

[49] 10. Kurti, S. etj.-etc. Fjalor politeknik anglisht-shqip - English-Albanian Polytechnic Dictionary,

[50] Tiranë, 1991.

[51] 11. Pllana, G. Formimi i terminologjive teknike shqipe mbi bazën e leksikut të përgjithshëm

[52] (Procese të krijimit, të pasqyrimit në gjuhë dhe të standardizimit) - Formation of Albanian

[53] technical terminologies on the basis of the general lexicon (Processes of creation, language

[54] reflection and standardization), QSA IGJL, Botimet Albanologjike - Albanological

[55] Publications, p. 9 \&217, Tiranë, 2017. [In Albanian]

[56] 12. Pllana, G.; Pllana, S.; Breznica P. A. (2020), Technical terms formed on the basis of the meanings of

[57] common words in the dictionaries of the Albanian language 1980 and 2006, RUSSIAN LINGUISTIC

[58] BULLETIN 3 (23) 2020, p. 121-124, Yekaterinburg, 2020.

[59] 13. Shvarts, V. V. The concise illustrated Russian-English dictionary of Mechanical Engineering,

[60] p. 53, Moscow, 1980.

[61] 14. Thomai, J. Studime për gjuhën shqipe IV - Studies on the Albanian language IV, ASA IGJL,

[62] p. 120-122, Tiranë, 2017. [In Albanian] 